Plant Tissue Cult. \& Biotech. 30(2): 179-187, 2020 (December)

(CBangladesh Assoc. for Plant Tissue Culture \& Biotechnology

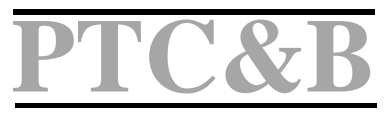

\title{
Antioxidant and Antibacterial Activities of Four Local Medicinal Plants
}

\author{
Barna Goswami, Shamoly Akter ${ }^{1}$, Nemai Chandra Nandi ${ }^{2}$, \\ Tanjina Akthar Banu, Shahina Akter, Sadia Afrin³, \\ Ahashan Habib and Salim Khan
}

Plant Tissue Culture Section, Biological Research Division, Bangladesh Council of Scientific and Industrial Research, Dhanmondi, Dhaka-1205, Bangladesh

Key words: Antioxidant activity, Medicinal plants, DPPH, Antibacetrial activity

\begin{abstract}
Potential antioxidant and antibacterial activity of methanolic, chloroformic and n-hexane leaf extracts of four local important medicinal plants like Ocimum americanum, $O$. basilicum, O. gratissimum and Centella asiatica was investigated. The methanolic leaf extracts of these plant species exhibited the potent DPPH free radical scavenging activity $\left(\mathrm{IC}_{50}\right.$ value, $2.67 \pm 0.01,14.17 \pm 0.11,60.22 \pm 0.01$ and $2.39 \pm 0.025 \mu \mathrm{g} / \mathrm{ml}$, respectively). Methanolic leaf extract of $C$. asiatica showed strongest antioxidant activity. Chloroformic leaf extracts possessed moderate antioxidant activity $\left(\mathrm{IC}_{50}\right.$ value of $79.44 \pm 0.05,110.56 \pm$ $0.02,54.95 \pm 0.05,101.0 \pm 1.0 \mu \mathrm{g} / \mathrm{ml}$, respectively) in all samples. The lowest antioxidant activity was recorded from $n$-hexane leaf extracts of O. americanum, O. gratissimum, $C$. asiatica and Ocimum basilicum (IC50 value 147.87 $\pm 0.06,378.19 \pm 2.65,104.65 \pm 0.39,467.58 \pm$ $0.52 \mu \mathrm{g} / \mathrm{ml}$, respectively). Methanolic and chloro-formic leaf extracts showed antibacterial activity against both Gram-positive and Gram-negative pathogenic bacteria, namely Bacillus megaterium, Escherichia coli, Pseudomonas aeruginosa and Salmonella typhi. Methanolic leaf extract of O. americanum and chloroformic extract of C. asiatica showed excellent antimicrobial activity.
\end{abstract}

\section{Introduction}

Natural antioxidants are being extensively studied for their ability to protect organisms and cells from damage caused by oxidative stress. Medicinal plants are in general, harmless sources for obtaining natural antioxidants. There is an increasing demand to

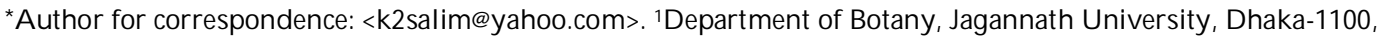
Bangladesh. ${ }^{2}$ Medicinal and Aromatic Plant Research Division, BCSIR Laboratories Chittagong, Chattogram 4220, Bangladesh. 3Incepta Pharmaceuticals Ltd., Savar-1341, Dhaka, Bangladesh.

DOI: https://doi.org/10.3329/ptcb.v30i2.50688 
evaluate the antioxidant properties of the plant extracts and in the last years, the attention has been focused on the antioxidant products from natural sources (Lobo et al. 2010 and Amiri 2010). Many pharmacological studies have shown that extracts of some antioxidant plants possess anti-inflammatory, anti-allergic, anti-tumor, anti-bacterial, anti-mutagenic and anti-viral activities to a greater or lesser extent. Today the large numbers of drugs are derived from medicinal plants, like morphine from Papaver somniferum, ephedrine from Ephedra vulgaris etc. The medicinal plants are rich in secondary metabolites which are potential sources of drugs and essential oils of therapeutic importance (www.intechophen.com).

Ocimum spp. and Centella asiatica are widely used in Bangladesh by the traditional medical practitioners in day to day practice. Generally, Ocimum spp. of the Lamiaceae family rich in polyphenolic compounds and a large number of them are well known for their antioxidant properties (Klaudija et al. 2016). In this regard, O. basilicum, $O$. americanum and $O$. gratissimum are very important members of this family for their medicinal value. Ocimum sp. is extensively used in traditional medicine (Javanmardi et al. 2002) and exhibits phytotherapeutic properties (Maria et al. 2008), antimicrobial (Ram et al. 2011), antifungal (Zhang et al. 2009), as well as antioxidant and insect repellent activities (Telci et al. 2009 and Kweka et al. 2008).

C. asiatica is a prostrate stoloniferous plant that belongs to Apiaceae and indigenous to Bangladesh (Varrier 1997). The therapeutic use of $C$. asiatica with its wide range of application has been documented in South East Asia and Bangladesh in particular for centuries. C. asiatica is effectively being used in the treatment of fever, jaundice, dysentery, diarrhea, mental illness within the frame of traditional medicine of Bangladesh (Ahmed 2009).

Despite the popular use of these medicinal plants in Bangladesh there is no reliable data available about the antioxidant and antimicrobial potential of these plants. So, efforts should be made to evaluate the antioxidant and antimicrobial properties of these plants. The aim of this work was to analyze antioxidant and antibacterial activity of three widely used species of Ocimum, namely O. americanum, O. basilicum, O. gratissimum and Centella asiatica.

\section{Materials and Methods}

Leaves of four local important medicinal plants like Ocimum americanum, O. basilicum, $O$. gratissimum and Centella asiatica were collected from medicinal plant garden of BCSIR Laboratories Chitttagong, Chattogram. After collection leaves were dried under shade at $25-27^{\circ} \mathrm{C}$ and powder was made using an electric blender. The powder was stored at $4^{\circ} \mathrm{C}$ in air tight container. The air-dried powdered leaf materials $(200 \mathrm{~g})$ of four plants were extracted with 550, 600 and $650 \mathrm{ml}$ of solvents $n$-hexane, chloroform and methanol separately in succession. The plant extracts were then evaporated, dried and stored in a beaker at $4^{\circ} \mathrm{C}$ till use. 2, 2-diphenyl-1-picryl hydrazyl (DPPH) free radical scavenging 
assay was used for determining antioxidant activity. The antioxidant potential of the crude extracts were determined on the basis of their scavenging activity of the stable dark-colored crystalline powder 2, 2-diphenyl-1-picryl hydrazyl free radical that has significant applications in laboratory research. The free radical scavenging property of extracts were analyzed by 1, 2-diphenyl 1-picryl hydrazyl assay developed by BrandWilliams et al. 1995. In determining DPPH free radical scavenging activity, different concentrations $(1.75,3.13,6.25,12.5,25,50,100,200$ and $400 \mu \mathrm{g} / \mathrm{ml})$ of the extracts and the positive control (Quercetin) were prepared with pure ethanol. Then $2 \mathrm{ml}$ of $0.004 \% \mathrm{DPPH}$ solution was added in test tube of different extracts. The test tubes were allowed to stand at dark for $30 \mathrm{~min}$ to complete the reaction and then absorbance was recorded at $517 \mathrm{~nm}$. The decrease in absorbance with blank was also measured. Negative control was prepared in the same way as the sample except addition of sample or standard. Percent scavenging activity was calculated using the formula: scavenging activity $=(\mathrm{A} 0-\mathrm{A} 1) / \mathrm{A} 0$ $\times 100 \%$, where A0 is the absorbance of control, and A1 is the absorbance of sample or standard. The experiment was carried out in triplicate. By using the equation $y=m x+c$ (where $\mathrm{c}$ is intercept and, $\mathrm{m}$ is slope); IC 50 value of extract was calculated.

Crude leaf extracts ( $n$-hexane, chloroformic and methanolic) of O. americanum, $O$. basilicum, O. gratissimum and C. asiatica were used to evaluate the antibacterial activity by using disc diffusion method. One Gram-positive pathogenic bacteria (Bacillus megaterium ATCC 18) and three Gram-negative pathogenic bacteria Escherichia coli; ATCC 8739, Pseudomonas aurigonisa; ATCC 2783318 and Salmonella typhi; ATCC 13311 were used in this test. A single bacterial colony was cultured in $25 \mathrm{ml} \mathrm{LB}$ broth for $24 \mathrm{hrs}$ at $37^{\circ} \mathrm{C}$ and the liquid culture was spread uniformly on nutrient agar plates using a sterile cotton swab. The plates were kept for 15 minutes and then used for the sensitivity test. Gentamycin (10 mcg/disc) were used as standard antibiotic. The sterile filter paper discs were prepared by adding $500 \mu \mathrm{g}$ extracts per disc. The negative control was $100 \%$ ethanol.

One Petri dish was arbitrarily divided in four parts where one negative control disc, one antibiotic disc and two extract discs were placed. The plates were then incubated at $37^{\circ} \mathrm{C}$ for 18 to 24 hours. After the incubation, the plates were observed for inhibition zone and were measured using scale in millimeter. The tests were repeated three times to ensure reliability.

\section{Results and Discussion}

Antioxidant activity of leaf extracts of Ocimum americanum, O. basilicum, O. gratissimum, and Centella asiatica were examined by DPPH free radical scavenging assay. Quercetin was used as a standard. Among three leaf extracts of the plants methanolic leaf extract showed lowest IC 50 value $(2.67-60.22 \mu \mathrm{g} / \mathrm{ml})$ compared to standard Quercetin $(2.28 \pm$ $0.01 \mu \mathrm{g} / \mathrm{ml}$ ) (Table 1). Chloroformic leaf extract exhibited lower IC 50 value (54.95 - 110.56 $\mu \mathrm{g} / \mathrm{ml})$ and $n$-hexane leaf extract showed the least antioxidant activity (147.87 -467.58 
$\mu \mathrm{g} / \mathrm{ml})$. Comparison of $\mathrm{IC}_{50}$ values of different plant extracts with standard Quercetin are presented in Fig. 1. It was previously reported that cysteine, glutathione, ascorbic acid, tocopherol, polyhydroxy aromatic compounds and aromatic amines could reduce and decolorize DPPH by their hydrogen donating ability (Blois 1958,

Table 1. DPPH-free radical scavenging activity.

\begin{tabular}{lll}
\hline Solvent system & Plant species & $\mathrm{IC}_{50}$ value $\mu \mathrm{g} / \mathrm{ml}$ \\
\hline Standard & Quercitin & $2.28 \pm 0.01$ \\
Methanolic & O. americanum & $2.67 \pm 0.01$ \\
& C. asiatica & $2.39 \pm 0.025$ \\
& O. basilicum & $14.17 \pm 0.11$ \\
& O. gratissimum & $60.22 \pm 0.01$ \\
Chloroformic & O. americanum & $79.44 \pm 0.05$ \\
& O. basilicum & $110.56 \pm 0.02$ \\
& O. gratissimum & $54.95 \pm 0.05$ \\
$n$-hexane & C. asiatica & $101.0 \pm 1.0$ \\
& O. americanum & $147.87 \pm 0.06$ \\
& O. basilicum & $467.58 \pm 0.52$ \\
& O. gratissimum & $378.19 \pm 2.65$ \\
& C. asiatica & $104.65 \pm 0.39$ \\
\hline
\end{tabular}

Results are the average of triplicate measurements $\pm \mathrm{Sd}$.

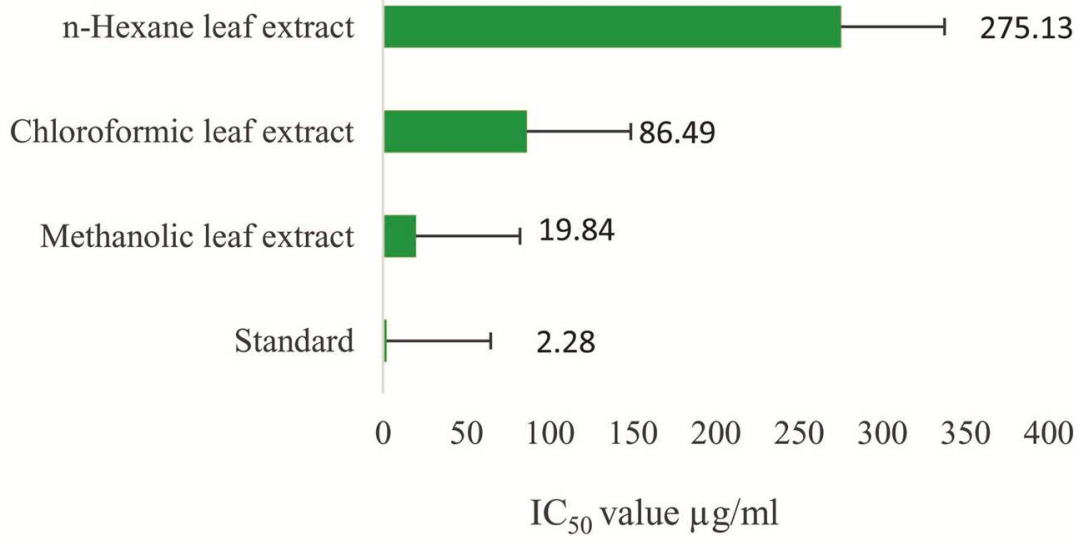

Fig. 1. Comparison of average $\mathrm{IC}_{50}$ values of methanolic, chloroformic and $n$-hexane leaf extracts of O. basilicum, O. americanum, O. gratissimum and C. asiatica with (Quercitin).Values are taken by three replicate determinations $(n=3) \pm S d$. IC 50 values of methanolic leaf extracts of all the plants are close to IC 50 value of standard. 
Hossain et al. 2015). Therefore, methanolic leaf extracts seem to possess hydrogen donating capability as they tend to extract mostly polar compounds from the plant material and showed potent antioxidant activity.

The $\mathrm{IC}_{50}$ value of methanolic leaf extracts of $O$. americanum, O. basilicum and $C$. asiatica were found $2.67 \pm 0.01,14.17 \pm 0.11,2.39 \pm 0.025 \mu \mathrm{g} / \mathrm{ml}$, respectively (Table 1). On the otherhand, methanolic leaf extract of $O$. gratissimum showed the least antioxidant activity. DPPH-free radical scavenging activity of methanolic leaf extracts of $C$. asiatica, $O$. americanum and $O$. basilicum, respectively are presented in Fig. 2 . The $\mathrm{IC}_{50}$ value of methanolic leaf extracts of $O$. americanum, $O$. basilicum and $C$. asiatica clearly indicated that the concentration of leaf extracts was needed to scavenge $50 \%$ of the free radical which was very close to the $\mathrm{IC}_{50}$ value of standard $(2.28 \mu \mathrm{g} / \mathrm{ml}$, where regression equation, $y=23.07 x+41.64, R_{2}$ value $=0.566$, data not shown). Therefore, methanolic leaf extract showed the potent antioxidant activity. C. asiatica showed the highest antioxidant activity (Regression equation, $y=25.75 x+40.18, R_{2}$ value $=0.524$, data not shown) from methanolic leaf extract (Fig. 2). Yadav et al. 2017 also reported that C. asiatica showed

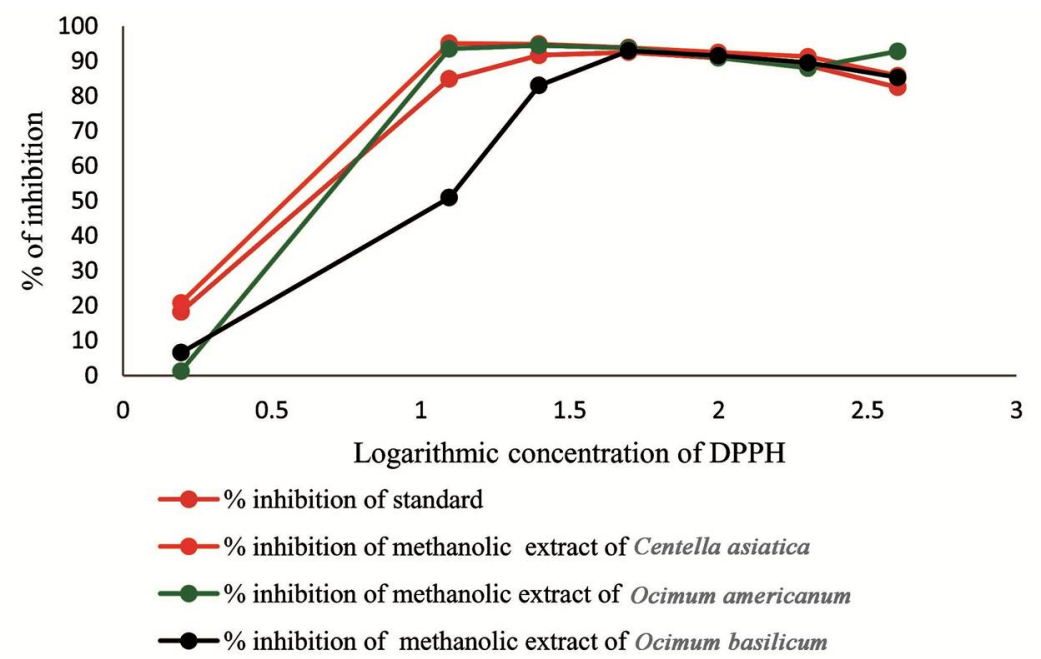

Fig. 2. DPPH radical scavenging assay of methanolic leaf extracts of C. asiatica, O. americanum and O. basilicum.

potential antioxidant activity using different solvent extracts. It was also in good agreement with the findings of Afrin et al. (2016), who reported that methanolic extract of Caesalpinia crista leaves acts as an antioxidant. Agarwal et al. (2017) also reported that methanolic root extract of O. kilimandscharicum and O. sanctum showed potent antioxidant activity. Sunitha and Rani (2017) reported that methanolic seed extracts of $O$. americanum showed the highest antioxidant activity. Strong antioxidant activity of methanolic extact of $O$. basilicum was also reported by Jayasinghe et al. (2003). 
On the other hand, chloroformic leaf extract of all plants used in this study showed moderate antioxidant activity by comparing the $\mathrm{IC}_{50}$ value may be due to the presence of non-polar or less polar compounds. During this study, O. gratissimum and O. americanum showed moderate antioxidant activity of chloroformic leaf extract in comparison with other plants. IC $\mathrm{C}_{50}$ value of chloroformic leaf extracts of $O$. gratissimum and O. americanum were $54.95 \pm 0.05$ and $79.44 \pm 0.05$, respectively. Afrin et al. (2016) reported that the leaf extract of chloroformic solvent system exhibited $50 \%$ inhibition $\left(\mathrm{IC}_{50}\right)$ at a concentration of 537.03 and $97.72 \mu \mathrm{g} / \mathrm{ml}$ by Cynometra ramiflora. Hakkim et al. (2008) also reported the antioxidant activity of $O$. gratissimum and $O$. americanum leaf extract.

N-hexane leaf extracts of all the medicinal plants showed the lowest antioxidant activity. The $\mathrm{IC}_{50}$ value of leaf extracts were found to be $147.87 \pm 0.06,378.19 \pm 2.65,104.65$ \pm 0.39 and $467.58 \pm 0.52 \mu \mathrm{g} / \mathrm{ml}$ for $O$. americanum, O. gratissimum, C. asiatica and $O$. basilicum, respectively. Patil et al. (2011) also reported that $n$-hexane extract of Ocimum sp. showed the lowest antioxidant activity. N-hexane extract of $C$. asiatica also showed the lowest in both antibacterial and antioxidant activity reported by Rattanakom and Yasurin (2014).

Table 2. Antibacterial activities of O. gratissimum, O. americanum, O. basilicum and C. asiatica leaf extracts.

\begin{tabular}{|c|c|c|c|c|c|}
\hline Bacteria & Plant species & $\begin{array}{l}\text { Antibiotic } \\
\text { gentamycin } \\
(\mathrm{mm})\end{array}$ & $\begin{array}{l}\text { Methanolic } \\
\text { leaf extract } \\
(\mathrm{mm})\end{array}$ & $\begin{array}{l}n \text {-hexane } \\
\text { leaf extract } \\
(\mathrm{mm})\end{array}$ & $\begin{array}{l}\text { Cholroformic } \\
\text { leaf extract } \\
(\mathrm{mm})\end{array}$ \\
\hline Escherichia coli & O. gratissimum & 21 & 25 & - & 10 \\
\hline (ATCC 8739) & C. asiatica & 25 & - & 14 & 16 \\
\hline $\begin{array}{l}\text { Salmonela typhi } \\
\text { (ATCC 13311) }\end{array}$ & O. americanum & 18 & 26 & - & 16 \\
\hline Bacillus megaterium & C. asiatica & 25 & 20 & - & 19 \\
\hline (ATCC 18) & O. basilicum & 28 & - & - & 9 \\
\hline Pseudomonas & O. basilicum & 19 & 25 & 9 & - \\
\hline $\begin{array}{l}\text { aeruginosa } \\
\text { (ATCC 2783318) }\end{array}$ & O. americanum & 21 & - & 10 & 10 \\
\hline
\end{tabular}

In case of antibacterial screening, all the leaf extracts (methanolic, chloroformic and $n$-hexane) of all medicinal plants used in this study showed potent to moderate antibacterial activity against B. megaterium, S. aureus, E. coli, P. aeruginosa and S. typhi (Table 2). Methanolic and chloroformic leaf extracts showed notable zone of inhibition compared to $n$-hexane extract. Methanolic leaf extract produced zone of inhibition was in between 20 and $26 \mathrm{~mm}$. Ocimum. basilicum showed the highest inhibition zone $(25 \mathrm{~mm})$ compared to antibiotic gentamycin $(19 \mathrm{~mm})$ against Pseudomonas aeruginosa using methanolic leaf extract (Fig. 3a). Ocimum gratissimum also showed similar inhibition zone $(25 \mathrm{~mm})$ against $E$. coli using methanolic leaf extract (Fig. 3b). In case of methanolic leaf extract maximum zone of inhibition was obtained $26.0 \mathrm{~mm}$ (Fig. 3c) against Salmonella 
typhi by $O$. americanum for $500 \mu \mathrm{g} /$ disc compared to standard gentamycin $(18.0 \mathrm{~mm}$ inhibition). In this study, methanolic leaf extracts showed most potential antibacterial activity. Venugopal et al. (2015) reported that methanolic extracts of Ocimum sp. showed maximum inhibition zone against $S$. aureus and B. subtilis which supports the present
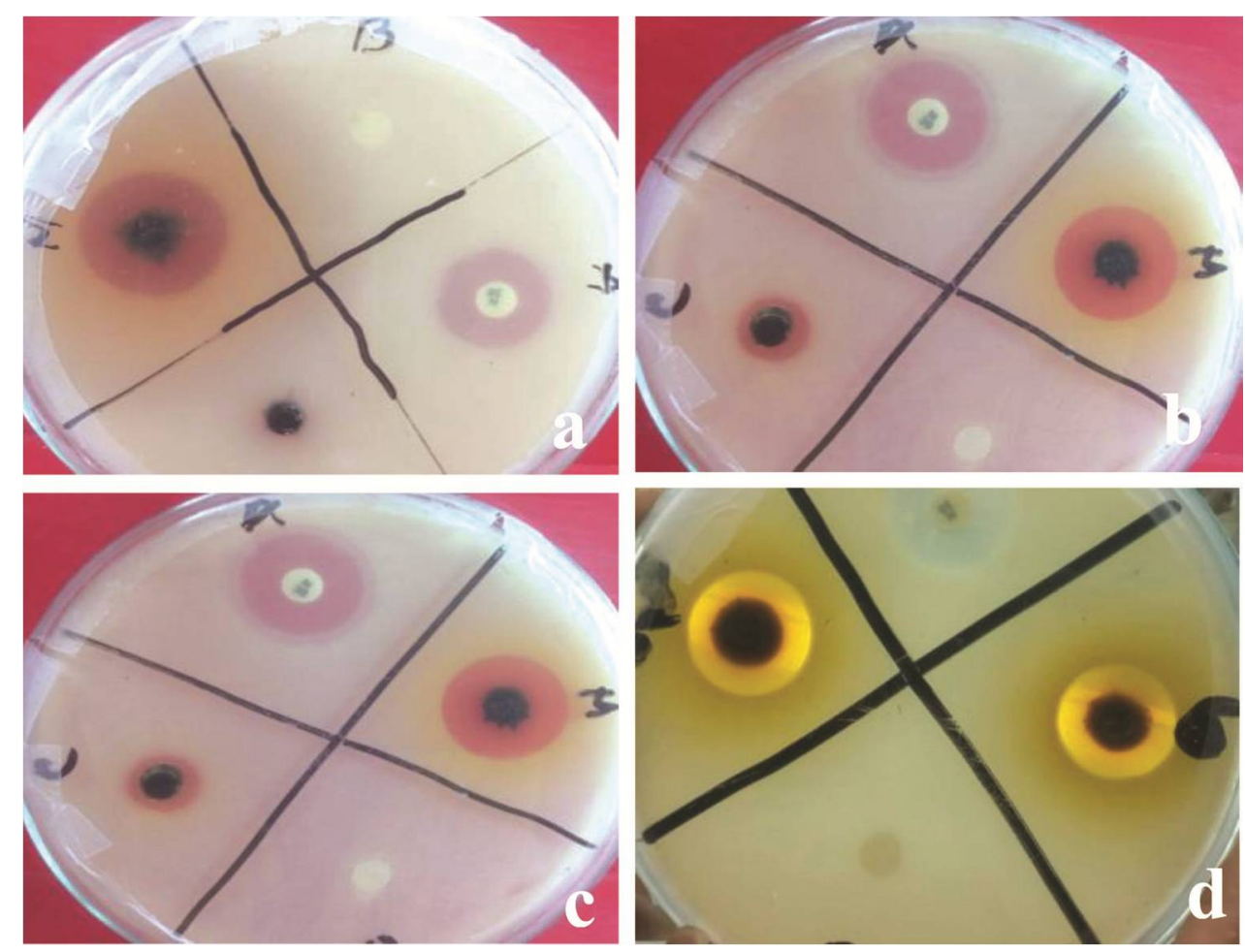

Fig. 3(a-d). Antibacterial activity of three species of Ocimum and C. asiatica. a. O. basilicum showing inhibition zone against Pseudomonas aeruginosa using methanolic leaf extract. b. O. gratissimum showing inhibition zone against E. coli using methanolic and chloroformic leaf extract c. O. americanum showing inhibition zone against Salmonela typhi using methanolic and chloroformic leaf extract. d. C. asiatica showing inhibition zone against Bacillus megaterium using methanolic and chloroformic leaf extract.

*Note: Methanolic leaf extract indicated as M, cholroformic leaf extract indicated as C in Petri dish.

observation. In chloroformic leaf extract inhibition zone ranged in between $9.0-19.0 \mathrm{~mm}$ (Table 2). Maximum zone of inhibition was $19.0 \mathrm{~mm}$ case of $C$. asiatica leaf extracts (Fig. $3 \mathrm{~d})$ obtained against Bacillus megaterium compared to standard gentamycin $(25.0 \mathrm{~mm}$ inhibition). According to Anjana et al. (2016), chloroform extracts exhibited wide range of antibacterial activity than that of methanolic extract in Ocimum. On the other hand similar antioxidant activity $n$-hexane leaf extracts produced lower zone of inhibition against the tested microorganisms. $n$-hexane leaf extract of $O$. basilicum, $O$. americanum and C. asiatica produced inhibition zone was in between 9 and $14 \mathrm{~mm}$.

Investigating all the results of antibacterial activity, it was found that the methanolic leaf extract of $O$. americanum showed excellent activity against both Gram-positive and 
Gram-negative bacteria. Deepak et al. (2015) investigated the antimicrobial activity of six plant species which are used in Indian folklore medicine traditionally against bacterial and fungal infections.

The present study indicated that the methanolic leaf extracts of O. americanum, $O$. basilicum, $O$. gratissimum and $C$. asiatica have potent antioxidant activity. Therefore, it could be concluded that these medicinal plants are good sources of natural antioxidants and antibacterial activity and good source for natural drugs.

\section{References}

Afrin S, Pervin R, Sabrin F, Rony S R, Sohrab MH, Islam ME, Islam KD and Billah MM (2016) In vitro antioxidant activity, antimicrobial and preliminary cytotoxic activity of Cynometra ramiflora - a mangrove plant. JMBFS 6(2): 844-850.

Afrin S, Pervin R, Sabrin F, Rony S R, Sohrab MH, Islam ME, Islam KD and Billah MM (2016) Assessment of antioxidant, antibacterial and preliminary cytotoxic activity of chloroform and methanol extracts of Caesalpinia crista L. Leaf. Bangladesh. J. Bot. 45(5): 1061-1068.

Agarwal K, Singh D, Jyotshna J, Ahmad A, Shanker K, Tandon S and Luqman S (2017) Antioxidative potential of two chemically characterized Ocimum (Tulsi) species extracts. Biomedical Research and Therapy 4(9): 1574-1590.

Ahmed ZU (2009) Encyclopedia of Flora and Fauna of Bangladesh. Asiatic Society of Bangladesh Dhaka. 6: 155-156.

Amiri H (2010) Antioxidant activity of the essential oil and methanolic extract of Teucrium orientale (L.) subsp. taylori (Boiss.). Rech. f. Iran J. Pharm. Res. 9: 417-423.

Anjana B, Lipsa M and Souvagyalami S (2016) In vitro clonal propagation of an important medicinal plant Ocimum tenuiflorum and assessment of its antimicrobial and phytochemical activities. IJMARRP 3(1): 268-284.

Blois MS (1958) Antioxidant determinations by the use of a stable free radical. Nature 181: 11991200.

Brand-Williams W, Cuvelier ME and Berset C (1995) Use of a free radical method to evaluate antioxidant activity. Lebensm.-Wiss. u.-Technol. 28: 25-30.

Deepak M, Arpita A, Rashmi A and Pratima M (2015) Micropropagation of an important medicinal plant Ocimum sanctum for field plantation. J. Soils Crop. 8: 232-236.

Hakkim FL, Arivazhagan G and Boopath R (2008) Antioxidant property of selected Ocimum species and their secondary metabolite content. J. Med. Plants Res. 2(9): 250-257.

Hossain SJ, Sultana MS, Ifterkharuzzaman M, Hossain SA and Taleb MA (2015) Antioxidant potential of common leafy vegetables in Bangladesh. Bangladesh J. Bot. 44: 51-57.

Javanmardi J, Khalighi A, Kashi A, Bais H and Vivanco J (2002) Chemical characterization of basil (Ocimum basilicum L.) found in local accessions and used in traditional medicines in Iran. J. Biol. Chem. 50: 5878-5883.

Jayasinghe C, Gotoh N, Aoki T and Wada S (2003) Phenolics composition and antioxidant activity of sweet basil (Ocimum basilicum L.). J. Agric. 51(15): 4442-4449. 
Klaudija C, Petek M, Grdisa M, Pintar J, Bedekovic D, Custic H M and Satovic Z (2016) Medicinal plants of the family Lamiaceae as functional foods - A review. Czech J. Food Sci. 34(5): 377-390.

Kweka EJ, Mosha F, Lowassa A, Mahande AM and Kitau J (2008) Ethnobotanical study of some of mosquito repellent plants in north-eastern Tanzania. Malays. J. Pathol. 7: 1

Lobo V, Patil A, Phatak A and Chandra N (2010) Free radicals, antioxidants and functional foods: Impact on human health. Pharmacogn. Rev. 4: 118-126.

Maria B, Zenovia O, Simona D, Ştefania S, Elena T, Marius Ş and Craita MR (2008) Research regarding the volatile oils composition for Ocimum basilicum L. and their possible phytotherapeutic effects. Am. J. Ind. Med. 5: 35-40.

Patil D, Dinanath, K Mhaske, Dnyandeo, Wadhawa and Gurumeet (2011) Antibacterial and antioxidant study of Ocimum basilicum Labiatae (sweet basil). J. Adv. Pharma. Ed. Res. 2: 104-112.

Ram SV PSB, Rajendra CP, Dharmendra S and Amit C (2011) Chemical composition and antibacterial activity of essential oil from two Ocimum sp. grown in sub-tropical India during spring-summer cropping season. Asian. J. Agric. Sci. 6: 211-217.

Rattanakom S and Yasurin P (2014) Review: Antibacterial, antioxidant and chemical profile of Centella asiatica. Biomed Pharmacol J. 7(2): 3042.

Sunitha K and Rani NC (2017) Evaluation of antioxidant properties of Ocimum americanum L. Seeds. J. Pharm. Sci. Innov. 6(6): 2277-4572.

Telci I, Elmastas M and Sahin A (2009) Chemical composition and antioxidant activity of Ocimum minimum essential oils. Chemistry Int. 45: 568-571.

Varrier PS (1997) Indian medicinal plant. Orient Longman Limlited, Madras. 11: 51-52.

Venugopal G, Venkateswara and Allu PR (2015) In vitro propagation of O. tenuiflorum var. CIMAYU from nodal explants. J. Applied Bioscience Res. 6: 1-7.

Yadav MK, Singh SK, Tripathia JS and Tripathi YB (2017) Phytochemical screening and In vitro antioxidant activity of Centella asiatica extracts. International J. Phytomedicine. 9: (61).

Zhang JW, Li SK and Wu WJ (2009) The main chemical composition and in vitro antifungal activity of the essential oils of Ocimum basilicum L. var. pilosum (Willd.) Benth. Mol. Med. 14: 273-278. www.intechophen.com 